\title{
BIOCLIMATIC STRATEGIES FOR THE CITY OF TANGARÁ DA SERRA / MT - BRAZIL
}

\author{
DALLASTRA, Maurício - mauricio.dallastra@universo.univates.br \\ Universidade do Vale do Taquari / UNIVATES
}

SILVA, Andréia Fernandes da - andreia.fernandes@unemat.br Universidade do Estado do Mato Grosso /UNEMAT

SPINELLI, Rodrigo - rspinelli@univates.br Universidade do Vale do Taquari / UNIVATES

DALLACORT, Rivanildo - rivanildo@unemat.br Universidade do Estado do Mato Grosso /UNEMAT

DALZOCHIO, Marina Schmidt - marina.dalzochio@univates.br Universidade do Vale do Taquari / UNIVATES

KONRAD, Odorico - okonrad@univates.br Universidade do Vale do Taquari / UNIVATES

\begin{abstract}
This paper aims to present the bioclimatic strategies for Tangará da Serra, located in the southwest region of the state of Mato Grosso. The focus of this research is to seek alternatives to ensure adequate thermal performance of buildings by promoting energy efficiency and environmental comfort. This work has a great relevance to the municipality since there are no publications that provide specific guidelines for the design of architectural projects adapted to the local climate. For this purpose, the bioclimatic chart of Tangará da Serra - Mato Grosso, was elaborated using climatic data collected from 2004 to 2017 by the meteorological station of the Universidade do Estado de Mato Grosso. From this information, the monthly and annual averages were established, thus generating the provisional weather conditions of the region, which were inserted in the software Analysis Bio. Finally, the city's bioclimatic chart was obtained, which resulted in the annual periods in which the climate is considered comfortable, as well as the bioclimatic strategies to promote thermal comfort in buildings during periods of higher and lower temperatures. The result of this paper emphasizes the natural ventilation and the thermal inertia of the materials as the main strategies to be adopted in the design and construction of buildings in Tangará da Serra - Mato Grosso.
\end{abstract}

KEYWORDS: bioclimatology; bioclimatic strategies; energy efficiency; Tangará da Serra.

\section{ESTRATÉGIAS BIOCLIMÁTICAS PARA A CIDADE DE TANGARÁ DA SERRA / MT - BRASIL}

RESUMO: Este artigo tem como objetivo apresentar as estratégias bioclimáticas para a cidade Tangará da Serra, localizada na região sudoeste do estado de Mato Grosso. O cerne desta pesquisa concentra-se em buscar alternativas para garantir desempenho térmico em edifícios promovendo a eficiência energética e conforto ambiental. Este trabalho é de grande relevância para o município uma vez que não há publicações que forneçam diretrizes específicas para a concepção de projetos arquitetônicos adaptados ao clima local. Para tanto, elaborou-se a carta bioclimática de Tangará da Serra/MT utilizando dados climáticos coletados desde 2004 a 2017 pela estação meteorológica da Universidade do Estado de Mato Grosso. De posso destas informações, estabeleceu-se as médias mensais e anuais, respectivamente, gerando, assim, as normais climatológicas provisórias da região, que foram inseridas no software Analysis Bio. Por fim obteve-se a carta bioclimática do município a qual apresentou como resultado os períodos anuais em que o clima é considerado confortável, bem como as estratégias bioclimáticas para promoção de conforto térmico nas edificações nos períodos de maior e menor 
temperaturas. O resultado do artigo enfatiza a ventilação natural e a inércia térmica dos materiais como as principais estratégias a serem adotadas na concepção e construção de edifícios em Tangará da Serra/MT.

PALAVRAS-CHAVE: Bioclimatologia; estratégias bioclimáticas; eficiência energética; Tangará da Serra.

\section{INTRODUCTION}

The preoccupation with environmental comfort is verified in projects from earliest records regarding architecture, before the beginning of the Roman Empire, when Marcus Vitruvius Pollio writes De architectura libri decem (The Ten Books of Architecture), determining, in addition to other considerations respect for thematic, the systems of architecture, defending that it must present three basic points: firmitas, venustas and utilitas, that when translated means respectively solidity, beauty and utility or functionality (COLIN, 2000). This is also related to the conditions of habitability and the use of a building, showing that the environmental comfort has always been one of the concerns to guarantee the quality of a building (THOENES, 2003). Vitruvio also affirms the necessity to respect local conditions for designing projects when he states that:

It seems to be necessary to develop types of buildings in one way in Egypt, otherwise in Hispania, still differently in Pontus, as well as in Rome and so on according to the distinct properties of other lands and regions. This is due to the fact that in one part of the world the Earth is superheated by the action of the sun, while in another it is situated very far from it, just as in another part it is situated at an intermediate distance (POLIÃO, 2002, p. 143).

Since the beginning, environmental comfort is associated with the quality of life and well-being of individual. In Roman cities in the 2 nd century a.C., heating water and air systems were already used as a strategy to modify and adapt the climate to the requirement of comfort (ESPÍ, 1999). According to Rudofsky (1981) apud Lamberts, Dutra e Pereira (1997) the Mesa Verde civilization built their dwellings on basis of solar incidence and projection of shadows of stone slopes, so in the summer there would be shade over the dwellings, while in the winter the heat stored in the rock during the day (due to the slope of the sun in relation to the terrestrial globe) was returned to the interior of dwellings at night, thus guaranteeing thermal comfort.

Since the Industrial Revolution, important changes have emerged for society: electric power, rail transportation, industries and mass production, as well as other elements that have enabled significant change in the daily life of the population (CARLOS, 2013). In addition, the significant increase in the population in urban areas has caused a number of urban problems, in addition to increasing the need for spaces for housing, thus generating an increase in energy consumption and natural resources, contributing to a significant increase in pollution, aggravating the environmental issue (BRAGA; HESPANHOL; CONEJO, 2005).

In the civil construction context, the verticalization of buildings became possible from the mastery of metal and the advent of prefabricated structures, as well as other materials produced in series that allowed the accelerated 
construction of large structures that had as a feature the explicitness of the structure. modernity and the valorization of labor and productivity, resulting in imposing constructions whose typology (International Style) would be widespread to other places as a synonym of ascension and power (CARLOS, 2013).

In the United States large skyscrapers were built and their beauty and representativity were the inspiration for this style of building to be reproduced in various locations, including Brazil. However, the buildings deployed have become large overheated structures, as the climate difference between the US and Brazilian regions is clear. To remedy this problem, equipment was started to allow artificial conditioning of environments in order to ensure environmental comfort to individuals, resulting in a significant increase in electricity consumption (LAMBERTS; NARANJO, 2016). As a result, energy consumption in buildings is responsible for a significant portion regarding the environmental impacts observed in recent years (MATEUS, 2009).

Since earliest days of civilization, man inhabited buildings without use electricity for heating or cooling, and this exists only about 130 years for lighting purposes and 110 for environmental conditioning, thus totaling $1 \%$ of entire historical period (ROMÉRO, REIS, 2012).

The concern with energy efficiency is an important topic discussed nowadays, having as initial mark on 17 th October of 1973 , this date refers to the beginning of oil crisis. Thereby, the 1970's was marked by the need to rethink consumptions and reduce energy expenditure of fossil fuels and to seek new renewable alternatives. Until then, in the United States, large buildings consumed up to $100 \mathrm{kWh} / \mathrm{m}^{2}$ per month, which affirms the importance of intensifying research in energy and renewable sources (ROMÉRO, REIS, 2012).

According to Roméro e Reis (2012), in order to reverse the situation, arises between the years of 1973 and 1974, the International Energy Agency IEA which aim is to coordinate actions of energy consumption in the crisis situations. Thereafter, were drawn up the first regulations on energy efficiency. In the scope of buildings, the first regulations and laws with restrictions on energy consumption were developed, by different institutions dedicated to the subject and in several countries. Stands out, in France, the Centre Scientifique et Techique du Bâtiment - CSTB; in United Kingdon, the Building Research Establishment Group - BRE; in United States, the American Society of Heating, Refrigerating, and Air Conditioning Engineers - ASHRAE. These organizations and their publications guided the actions adopted in Brazil.

According to Lamberts and Naranjo (2016), the environmental comfort study is based on three essential factors, which are: the human well-being with respect to environment that surrounds it, including aspects related to hygien and salubrity of spaces; the type of user in environments for the most varied activities (intellectual, manual, among others); and energy conservation. It should be noted that there is a strong relationship between productivity and user satisfaction with the environment, which is greater as the individual feels well-being in space. In addition, environmental comfort becomes relevant due to the fact that humans spend more than $80 \%$ of their lives in built spaces (MANZANO-AGUGLIARO et al., 2015). 
Studies developed by American Ventilation Commission in 1916 have shown that thermal discomfort in work environments reduced the work performance between $15-40 \%$ when the temperatures are higher (FROTA; SCHIFFER, 2001). In this way, besides ensuring a pleasant environment, the study of thermal comfort aims to guarantee productivity, safety and health (physical and mental) of users.

Furthermore, it is necessary to pay attention to the question of the sick building syndrome (SBS), whose concept arises from the twentieth century when, in order to avoid the penetration of external pollution and to enable internal environmental conditioning, the architectural standards were changed to hermetically closed buildings, which constitute an atmosphere hostile to human health, as shown by research conducted by the World Health Organization - WHO (STERLING; COLLET; RUMEL, 1991). Dear and Brager (2002) find this, pointing to the natural ventilation of buildings as an efficient strategy for the promotion of thermal comfort, besides contributing to the reduction of symptoms associated with SBS.

Thermal comfort is, therefore, the usual term to indicate the degree of satisfaction of the human being with the thermal environment in which he is inserted. The dissatisfaction with the environment is due to the unstable heat balance which refers to the differences between the heat produced by human body and the heat lost to the environment. However, in addition to physical factors, the concept of thermal comfort also involves physiological and psychological issues and is therefore subjective matter. In this way, thermal neutrality can be considered as an important factor for satisfaction with thermal comfort of a given environment (RUPP; VÁSQUEZ; LAMBERTS, 2015).

It's at the stage of development of architectural project that the environmental comfort is defined by means of the form, volumetry, positioning in relation to solar radiation and incidence of winds, layout of openings and parameters of spaces dimensioning (KOWALTOWSKI; LABAKI, 1993). Thus, corrective measures in buildings already constructed are alternatives which demand greater consumption of resources (financial and material), coming from what proposes the sustainable development.

According to Manzano-Agugliaro et al. (2015), the study of thermal comfort and natural strategies are fundamental themes to ensure the reduction of environmental impacts generated by civil construction, meeting the proposition of sustainable development, since residential environmental conditioning is responsible for $20 \%$ of the population. Electricity consumption while in commercial buildings is equivalent to almost half of total electricity consumption (ELETROBRAS, 2007).

Currently, several technical standards have been elaborated in order to guarantee the thermal comfort in buildings and, consequently, to mitigate the environmental impacts generated by the buildings, besides taking care of salubrity of enclosures. Among these, NBR 15220, deals with the Thermal Performance of Buildings, developed by Brazilian Association of Technical Standards - ABNT (2005a), this normative presents guidelines to elaborate projects based on principle of bioclimatic architecture, which has as a characteristic the design of buildings considering the local climate. The third part of the normative - Brazilian bioclimatic zoning and constructive guidelines for single-family dwellings of social interest (ABNT, 2005b) - presents eight 
Brazilian bioclimatic zones, listing the main cities and their respective constructive strategies with the purpose of guaranteeing environmental comfort in built environment. In the state of Mato Grosso, only six municipalities present this data, and the closest ones to Tangará da Serra are Cuiabá and Diamantino, both corresponding to Bioclimatic Zone 7.

However, although the standard is in force, many projects are designed without considering the parameters presented, especially social housing - HIS, granted through public housing policies and programs, which follow a limited architectural standardization and, consequently, inefficient from the perspective of environmental comfort (MORENO; MORAIS; SOUZA, 2017). Studies also point out that, through the possible climate changes over the next decades, the adoption of bioclimatic measures in housing constructions is fundamental for the preservation of resources and the reduction of energy demand in the country (TRIANA; LAMBERTS; SASSI, 2018).

This work is justified by its relevance to the local reality, since the climate-related research references as a bioclimatic strategy were developed only for Cuiabá, the state capital, distant $240 \mathrm{~km}$ from the studied region. The state of Mato Grosso presents three of the main biomes of the country: Amazon, Cerrado and Pantanal, besides a wide climatic variety, since each municipality has its own geographic and topographic characteristics, which reinforces the relevance on the research in the interior municipalities (MATO GROSSO, 2018).

Thus, this article contributes to the quality of buildings, especially in thermal performance and energy efficiency, becoming relevant to sustainable development and serving as a theoretical contribution to scientific research in areas of climatology and civil construction.

\subsection{BIOCLIMATIC CHART}

Currently, economic development and the pursuit of quality of life have intensified the consumption of energy resources, especially in developing countries. In this sense, the emphasis on research that contributes to the reduction of energy consumption becomes relevant, especially in cities, which are responsible for significant energy demand. Research shows that industrialization and urbanization have a direct impact on energy consumption and CO2 emissions, and are higher as GDP per capita increases (LI; LIN, 2015). Another relevant factor in this context refers to global warming, which will cause an increase in the demand for energy resources and, consequently, increasing the environmental impact from civil construction (GUAN, 2012).

The application of bioclimatic strategies is of great relevance for the reduction of the environmental impacts from civil construction verified today, such as energy consumption and $\mathrm{CO} 2$ emissions, since comfort can be obtained by natural methods that do not require the use of devices for environmental conditioning (TIKOPOULOS; KARATZA; PARAVANTIS, 2004).

For Manzano-Agugliaro, et al., (2015) architecture has always played the role of protecting humans from the external natural environment while bioclimatic architecture proposes the interaction between interior and exterior with the purpose of ensuring comfort to the built environment, based on energy efficiency, human well-being and health and sustainability. 
Knowledge of the climate is essential for professionals of construction to design a comfortable building from the thermal point of view. The envelope (walls, floor, roof, openings and glazed surfaces) must be designed according to specific characteristics of climate, which are expressed through variables such as temperature, relative humidity, wind speed and direction, among others (LAMOTTA; LABAKI, 2009).

The bioclimatic chart is an instrument that provides the conditions for obtaining comfort in a built environment, through the analysis of the surrounding climate (BROWN \& DEKAY, 2004).

The first bioclimatic chart was developed by Victor Olgyay, whose research proposed to relate the sensation of comfort to climatic data (OLGYAY, 1963). Givoni (1992) identified that the methodology proposed by Olgyay was limited, especially for hot climate regions, because it did not consider the relationship between radiation and thermal inertia. Givoni, therefore, developed a methodology that proposes the bioclimatic chart, considering the temperature and humidity of the environment to delimit comfort zone and present bioclimatic strategies to guarantee thermal comfort, being a suitable methodology for warm climates (RUPP; GHISI, 2014).

The bioclimatic chart evaluates the zones of comfort, ventilation, evaporative cooling, thermal mass for cooling, air conditioning, humidification, thermal mass for heating, passive solar heating, among others, proposing, according to locality, the strategies necessary for a better performance with regard to thermal comfort in the built environment (MANZANO-AGUGLIARO, et al., 2015).

Zone 1 refers to temperature values ranging from 18 to $26{ }^{\circ} \mathrm{C}$ and relative humidity between 40 to $65 \%$, which statistically correspond to satisfaction with thermal comfort for at least $70 \%$ of the population. Zone 2 corresponds to the natural ventilation strategy as a means of promoting thermal comfort. To this end, it can be promoted from the arrangement of the building, according to the incidence of the prevailing winds of the place, as well as openings that allow cross ventilation in the environment, so that there is constant air renewal, among others (MANZANO-AGUGLIARO, et al., 2015). In Brazil, this strategy is very important and performs well in promoting thermal comfort in warm weather periods and regions (COSTA; FREIRE; KIPERSTOK, 2019). However, due to the solar incidence on the openings, it is necessary to combine shading strategies that allow air permeability and direct solar radiation obstruction. An example is brise-soleil whose characteristic is to promote shading and allow the entry of natural light and ventilation, thus promoting thermal and visual comfort (OUAHRANI; AL TOUMA, 2018).

Zone 3 refers to evaporative cooling, which consists in reducing the internal temperature by evaporating water, thereby increasing the relative humidity of the air. The strategy that proposes the thermal inertia of the cooling envelope materials is zone 4, which suggests the knowledge of the physical properties of the materials used in the walls and roofs in order to mitigate the external thermal gains inside the buildings. Zone 10 and 11 propose the association of this with natural ventilation and / or evaporative cooling. Air conditioning is suggested by zone 5 , which has the characteristic of reducing the temperature and relative humidity of the air and applies to extreme situations when natural means are not sufficient. Zone 6 suggests humidifying the 
environment to ensure improved thermal comfort and health of the enclosure, as dry environments can lead to health problems (MANZANO-AGUGLIARO, et al., 2015).

Zone 8 corresponds to passive solar heating, which refers to the natural heating of the environment by solar radiation (renewable energy) and zone 7 associates this with thermal inertia to increase thermal gains in the environment. Zone 9, as well as zone 5, suggests climate conditioning of the environment artificially. These are convenient strategies for cold weather or harsh winters (VERBEKE; AUDENAERT, 2018).

Thus, the bioclimatic architecture contributes significantly to the reduction of energy consumption compared to conventional buildings, directly contributing to the environmental preservation and conservation of the planet's resources (SOUTULLO et al., 2016).

\subsection{TANGARÁ DA SERRA / MT-BRAZIL}

The study area comprises the city of Tangará da Serra, in the state of Mato Grosso, located between Tapirapuã and Parecis (Figure 1). The climate is tropical hot and sub humid, with well-marked periods of rain throughout the year (DALLACORT, et al, 2011). This characteristic is related to the fact that this city is inserted in a region known as cerrado, where the rains are concentrated between spring and summer (MARCUZZO; ROCHA; MELO, 2011). The city presents an average annual temperature between $24.4{ }^{\circ} \mathrm{C}$ and $26.1{ }^{\circ} \mathrm{C}$, with maximum temperature of $38^{\circ} \mathrm{C}$ and minimum of $26^{\circ} \mathrm{C}$, according to the Socioeconomic Profile of Tangará da Serra, elaborated by the Núcleo de Extensão e Pesquisas Socioeconômicas e Contábeis - NEPEC (NEPEC, 2011).

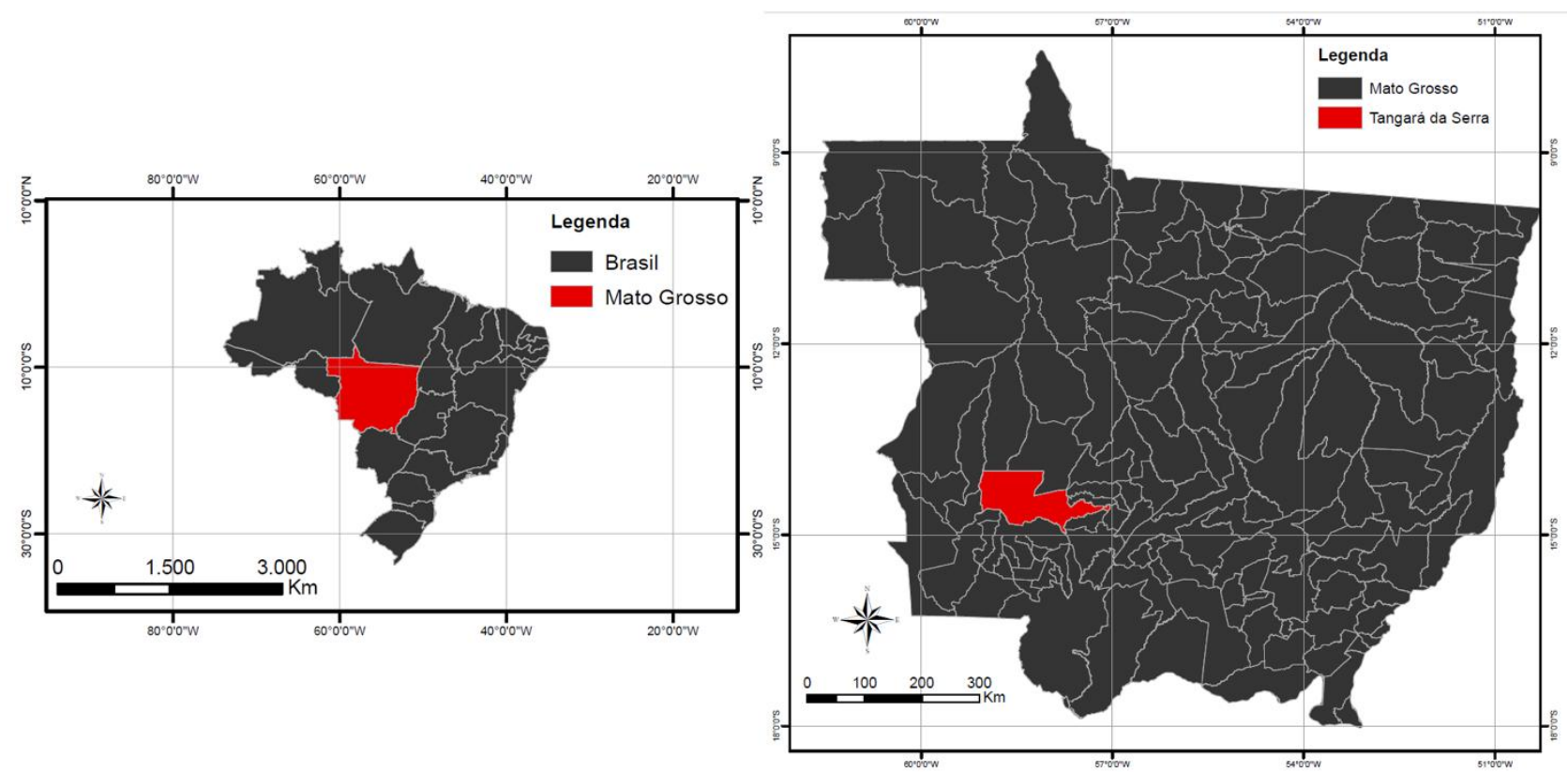

Figure 1 - Location of state of Mato Grosso in relation to the country and location of Tangará da Serra in relation to the state, respectively. 
Tangará da Serra is the sixth most populous city in state of Mato Grosso, with a population estimated in 2018 of 101,764 inhabitants according to Instituto Brasileiro de Geografia e Estatística - IBGE (2018).

Regarding civil construction, the current scenario of the municipality is favorable, approximately 105 regulated companies operating in sector, of which $80.1 \%$ work directly in the project design and execution phases (IBGE, 2018). The city has two universities (public and private) with civil engineering courses and related areas, and the private institution also offer the course of architecture and urbanism, which develops research in the area of construction.

Around $82 \%$ of the residential buildings are composed by masonry (with and without coating), which indicates this constructive typology is the most usual among the projects executed in the city (IBGE, 2018). Therefore, investigating suitable bioclimatic strategies for Tangará da Serra city is important for development of architectural projects and the choice of construction techniques and materials consistent with the local climate and, consequently, contribute to an efficient and thermally comfortable building.

\subsection{OBJECTIVE}

This research aims to elaborate the Bioclimatic Chart for Tangará da Serra / MT, based on meteorological data collected between the years 2004 to 2017 (period of 14 years), formatted in provisional weather conditions, presenting the bioclimatic strategies for development and application in civil construction at local level.

\section{METHODOLOGY}

For the development of this paper, the methodology was based on similar work already developed for another locality (SPINELLI, et al., 2017), used from the database provided by Laboratório de Agrometeorologia of Universidade do Estado de Mato Grosso - UNEMAT, Tangará da Serra campus, by means of an automatic meteorological station whose geographic coordinates are: latitude $14^{\circ}$ $39^{\prime} \mathrm{S}$, longitude $57^{\circ} 25^{\prime} 53.5^{\prime \prime} \mathrm{W}$, with an altitude of 321.5 meters. In order to measure the mean, minimum and maximum temperatures and the relative humidity of the air, the sensor model CS215 was used, manufactured by Campbell Scientific Ltd. The CS106 barometer provided atmospheric pressure data. All data were collected and stored in a datalogger, model CR1000, also manufactured by Cambell Scientific Ltd. This equipment performs the reading per second, and every hour the system provides the hourly average (PALHANA MOREIRA, et al., 2015).

With these data, the averages were established for each climatic variable, between the years of 2004 and 2017, in order to establish the provisional weather conditions. These are, according to World Meteorological Organization (WMO), averages of climatic variables, raised for at least 10 years, calculated when there are no climate records for a period of 30 consecutive years (INSTITUTO NACIONAL DE METEOROLOGIA - INMET, 2019).

Through the software Analysis Bio, developed by the Laboratório de Eficiência Energética em Edificações - LabEEE, linked to Núcleo de Pesquisa em 
Construção do Departamento de Engenharia Civil of the Universidade Federal de Santa Catarina, it is possible to dispose the climatic data collected, inserting the provisional weather conditions for the program to present, on a psychrometric diagram, the strategies appropriate to that locality.

\subsection{DATA ANALYSIS}

The collected data were arranged in Excel software, through which it was possible to establish the average daily climatic variables of the whole period (between 2004 and 2017). Then, the monthly average was established for each month, totaling 168 averages of each variable. Finally, the averages of the monthly averages of 14 years were measured, in order to stipulate the average values for each month of the year, resulting in the temporary climatologic conditions of the city. The result of these calculations is shown in Table 1.

Table 1 - Climatic data: Average \pm standard deviation of every month between 2004 a 2017.

\begin{tabular}{|c|c|c|c|c|c|c|c|c|c|c|c|c|c|c|c|}
\hline \multirow[b]{2}{*}{ JAN } & \multicolumn{3}{|c|}{$\begin{array}{l}\text { AV. MIN. } \\
\left.\text { TEMP. ( }{ }^{\circ} \mathrm{C}\right)\end{array}$} & \multicolumn{3}{|c|}{$\begin{array}{l}\text { MEAN TEMP. } \\
\left({ }^{\circ} \mathrm{C}\right)\end{array}$} & \multicolumn{3}{|c|}{$\begin{array}{l}\text { AV. MAX. } \\
\text { TEMP. }\left({ }^{\circ} \mathrm{C}\right)\end{array}$} & \multicolumn{3}{|c|}{$\begin{array}{l}\text { AV. HUMID. } \\
(\%)\end{array}$} & \multicolumn{3}{|c|}{$\begin{array}{c}\text { AV. } \\
\text { PRESSURE }\end{array}$} \\
\hline & 21.58 & \pm & 0.48 & 24.62 & \pm & 0.52 & 29.98 & \pm & 1.61 & 80.89 & \pm & 5.34 & 960 & \pm & 1.08 \\
\hline FEB & 21.45 & \pm & 0.34 & 24.52 & \pm & 0.59 & 30.16 & \pm & 1.40 & 80.82 & \pm & 4.96 & 961 & \pm & 0.35 \\
\hline MAR & 21.79 & \pm & 1.12 & 24.88 & \pm & 1.93 & 30.84 & \pm & 0.74 & 79.58 & \pm & 4.97 & 961 & \pm & 0.63 \\
\hline APR & 20.72 & \pm & 056 & 24.65 & \pm & 0.55 & 30.51 & \pm & 0.73 & 77.94 & \pm & 5.46 & 962 & \pm & 0.51 \\
\hline MAY & 18.75 & \pm & 1.19 & 23.26 & \pm & 1.22 & 28.99 & \pm & 1.51 & 74.66 & \pm & 6.56 & 964 & \pm & 0.77 \\
\hline JUN & 17.88 & \pm & 1.03 & 23.49 & \pm & 0.94 & 30.19 & \pm & 0.91 & 66.64 & \pm & 6.34 & 965 & \pm & 0.72 \\
\hline JUL & 16.96 & \pm & 0.72 & 23.38 & \pm & 0.82 & 30.30 & \pm & 0.95 & 58.08 & \pm & 7.67 & 965 & \pm & 0.84 \\
\hline AUG & 18.63 & \pm & 1.24 & 25.56 & \pm & 1.09 & 33.13 & \pm & 1.07 & 49.45 & \pm & 5.82 & 964 & \pm & 0.80 \\
\hline SEP & 20.41 & \pm & 1.08 & 26.40 & \pm & 1.44 & 33.68 & \pm & 1.78 & 57.21 & \pm & 7.14 & 963 & \pm & 1.07 \\
\hline ОСТ & 21.23 & \pm & 0.34 & 26.00 & \pm & 0.61 & 32.97 & \pm & 0.95 & 69.87 & \pm & 4.75 & 961 & \pm & 0.52 \\
\hline NOV & 21.49 & \pm & 0.43 & 25.43 & \pm & 0.44 & 31.67 & \pm & 0.64 & 75.36 & \pm & 4.27 & 960 & \pm & 0.38 \\
\hline DEC & 21.48 & \pm & 0.31 & 24.88 & \pm & 0.50 & 30.82 & \pm & 0.78 & 78.58 & \pm & 4.89 & 960 & \pm & 0.90 \\
\hline
\end{tabular}

Then, using the Bioestat software, the correlations were performed between average temperature and relative humidity and average temperature and pressure. As a result, a negative correlation was observed for both cases (temperature and relative humidity: $r=-0.46 ; p=0.13$; and temperature and pressure: $r=-0.54 ; p=0.07$. Therefore, temperature and relative humidity and 
temperature and atmospheric pressure are associated, so when one of the variables increases the other decreases.

As regarding the rainfall index, Tangará da Serra / MT, presents two welldefined seasons, the dry season between May and September and the rainy season between October and April, with the highest occurrence of precipitation from January to March (DALLACORT, et al., 2011). Figure 2 shows the averages of maximum, mean and minimum temperatures respectively, indicating minimum and maximum values correspond to the dry period, comprising the month of July with the lowest temperature $\left(16.96^{\circ} \mathrm{C}\right)$ and September with the highest temperature $\left(33.68^{\circ} \mathrm{C}\right)$.

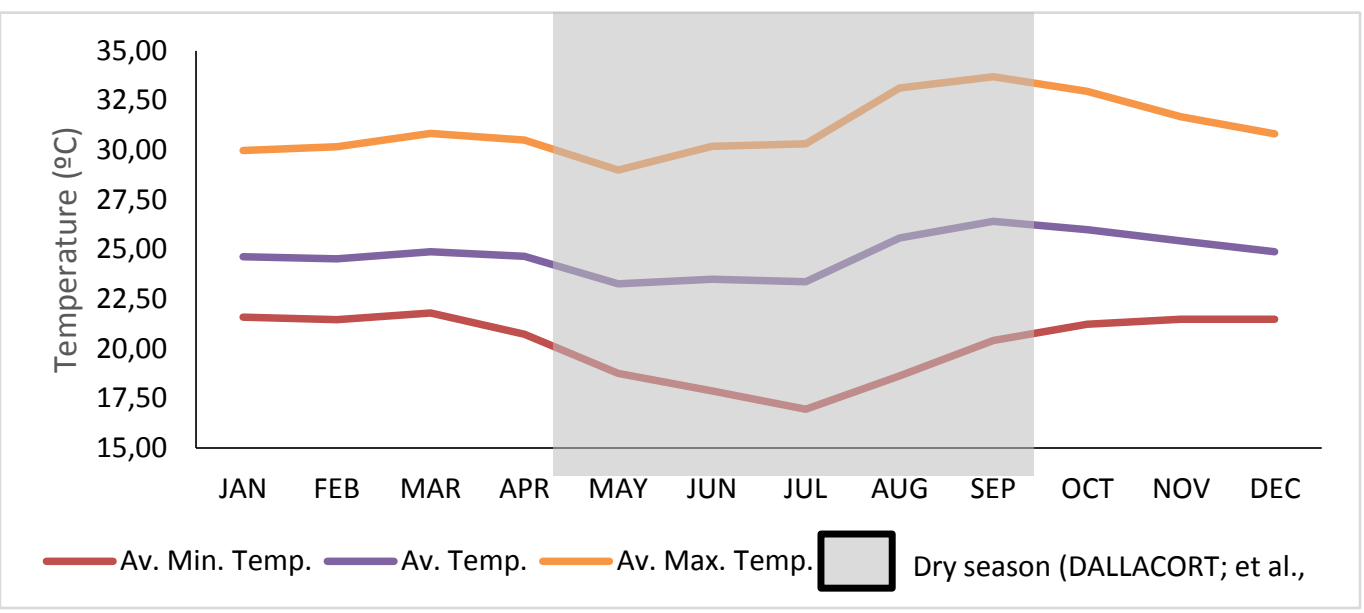

Figure 2 - Graph of the minimum, average and maximum temperature for Tangará da Serra / MT.

After the analysis and knowing the thermal conditions of the city, it was chosen to also evaluate the climatic variables in an isolated way, in order to verify, according to the averages of each year, the highest and lowest mean value. The Figure 3 shows that the year in which the average temperature was highest was 2015 , with a value of $25.57{ }^{\circ} \mathrm{C}$. It is also observed, although the difference between the lowest value $\left(24.12{ }^{\circ} \mathrm{C}\right.$ in the year 2004) and the highest $\left(25.57^{\circ} \mathrm{C}\right.$ in the year 2015$)$ is $1.45^{\circ} \mathrm{C}$, there is a tendency to increase between the beginning year of the sampling and the following years analyzed. A Generalized Linear Model (GLM) was used to verify if there is an annual average temperature increase over the years studied. The analysis revealed that there is a significant increase $\left(r^{2}=0.34 ; p=0.01 ; t=2,51\right)$, as expressed by the equation of line $Y=0.044 x-63.979$. This equation suggests that each year analyzed, there was an average increase of $0.044^{\circ} \mathrm{C}$ in temperature. 


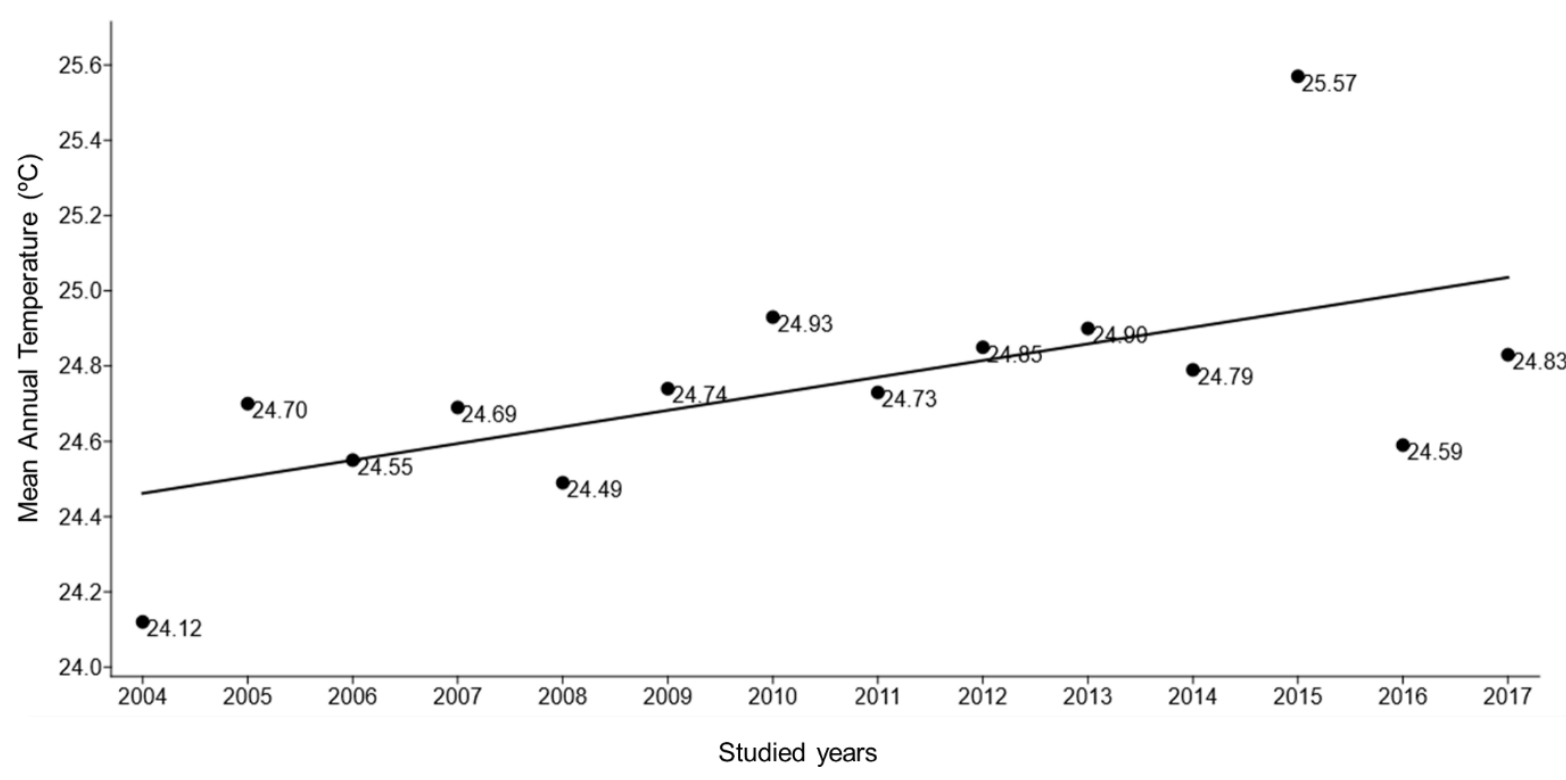

Figure 3 - Annual temperature averages between 2004 and 2017 for Tangará da Serra / MT.

The variable Relative Humidity (\%) was also verified. The year 2010 presented the lowest value, with $61.88 \%$, however, except for the years 2009, 2010, 2011 and 2012, all other years of the sample had averages of relative humidity above $70 \%$, according to Figure 4 . For the annual average relative humidity, the analysis revealed no significant standard $\left(r^{2}=0.01 ; p=0.70\right.$; $t=0,38)$, as expressed by the equation of line $Y=0.107 x-144.61$.

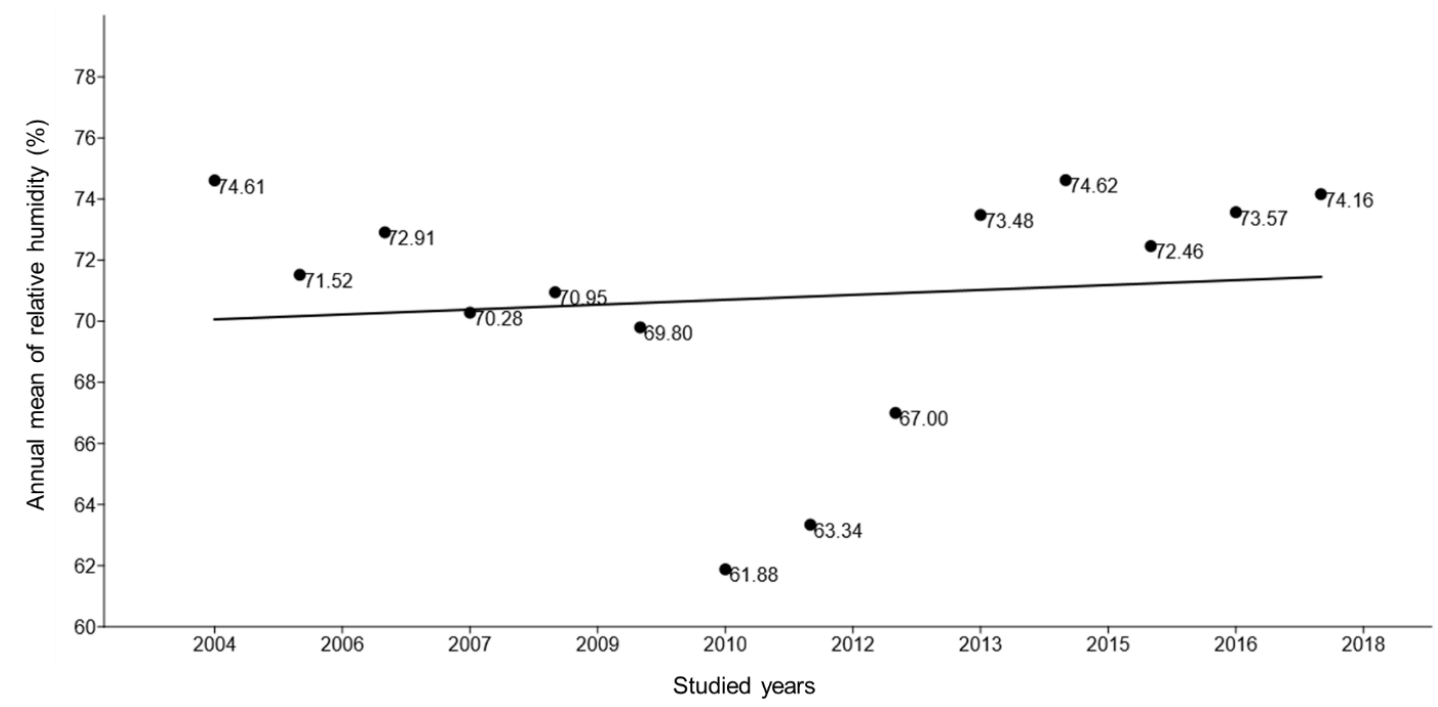

Figure 4 - Annual averages of relative humidity between 2004 and 2017 for Tangará da Serra / MT. 
In relation to atmospheric pressure $(\mathrm{hPa})$, there was a decrease in absolute values between 2004 and 2009, compared to the following years, with the maximum value of sampling occurring in 2016 at $962.93 \mathrm{hPa}$ (Figure 5). For the annual mean atmospheric pressure, the analysis also revealed no significant pattern $\left(r^{2}=0.06 ; p=0.40 ; t=087\right)$, as expressed by the equation of line $Y=$ $0.033 x-895.7$.

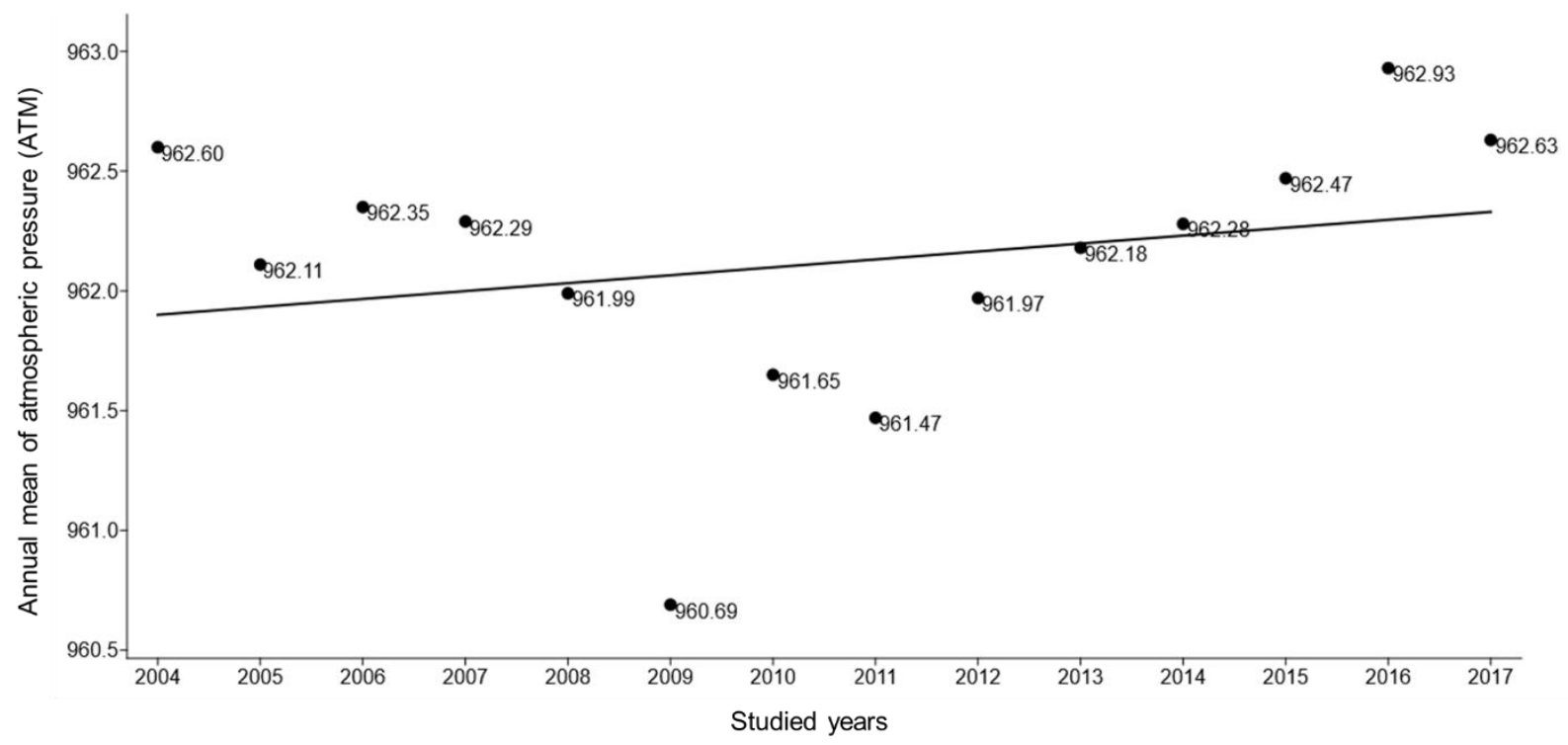

Figure 5 - Annual averages of atmospheric pressure between 2004 and 2017 for Tangará da Serra / MT.

The oscillation happens continuously due to the change in the specific mass of the air, caused by the temperature of the place and/or the water vapor content related to the altitude of the study site (ALMEIDA, 2016), in addition to other phenomena that directly interfere with this climate variable (GABRIEL; et. al., 2011).

In addition to these analyses, the tabulation of climatic data was also performed considering the absolute minimum and maximum temperatures of all monthly averages (Table 2), in order to compare to the calculated averages. It can be observed that there are differences between the presented values that vary from $0.58{ }^{\circ} \mathrm{C}$ (in January) to $2,23{ }^{\circ} \mathrm{C}$ (in August) between the average minimum and absolute minimum temperatures; and from $1.04^{\circ} \mathrm{C}$ (in March) to $2.399^{\circ} \mathrm{C}$ (in July) between the average maximum and absolute maximum temperatures. This is due to the different temperatures measured during all analyzed periods, previously verified (Figure 3 ). 
Table 2 - Climatic data: Absolute minimum and maximum temperatures and averages \pm standard deviation of all months between 2004 and 2017.

\begin{tabular}{|c|c|c|c|c|c|c|c|c|c|c|c|}
\hline \multirow[b]{2}{*}{ JAN } & \multirow{2}{*}{$\begin{array}{c}\text { ABSOLUTE. } \\
\text { MIN. TEMP. } \\
\text { ('o) } \\
21.00\end{array}$} & \multicolumn{3}{|c|}{$\begin{array}{l}\text { MEAN TEMP. } \\
\left({ }^{\circ} \mathrm{C}\right)\end{array}$} & \multirow{2}{*}{$\begin{array}{c}\text { ABSOLUTE. } \\
\text { MAX. TEMP. } \\
\left({ }^{\circ} \mathbf{C}\right) \\
31.56\end{array}$} & \multicolumn{3}{|c|}{$\begin{array}{c}\text { RELATIVE } \\
\text { HUMID. (\%) }\end{array}$} & \multicolumn{3}{|c|}{ PRESSURE } \\
\hline & & 24.62 & \pm & 0.52 & & 80.89 & \pm & 5.34 & 960 & \pm & 1.08 \\
\hline FEB & 20.77 & 24.52 & \pm & 0.59 & 32.29 & 80.82 & \pm & 4.96 & 961 & \pm & 0.35 \\
\hline MAR & 20.48 & 24.88 & \pm & 1.93 & 31.88 & 79.58 & \pm & 4.97 & 961 & \pm & 0.63 \\
\hline APR & 19.45 & 24.65 & \pm & 0.55 & 31.66 & 77.94 & \pm & 5.46 & 962 & \pm & 0.51 \\
\hline MAY & 17.23 & 23.26 & \pm & 1.22 & 31.05 & 74.66 & \pm & 6.56 & 964 & \pm & 0.77 \\
\hline JUN & 15.97 & 23.49 & \pm & 0.94 & 31.83 & 66.64 & \pm & 6.34 & 965 & \pm & 0.72 \\
\hline JUL & 15.39 & 23.38 & \pm & 0.82 & 32.69 & 58.08 & \pm & 7.67 & 965 & \pm & 0.84 \\
\hline AUG & 16.40 & 25.56 & \pm & 1.09 & 35.49 & 49.45 & \pm & 5.82 & 964 & \pm & 0.80 \\
\hline SEP & 18.44 & 26.40 & \pm & 1.44 & 36.07 & 57.21 & \pm & 7.14 & 963 & \pm & 1.07 \\
\hline ОСТ & 20.65 & 26.00 & \pm & 0.61 & 34.66 & 69.87 & \pm & 4.75 & 961 & \pm & 0.52 \\
\hline NOV & 20.46 & 25.43 & \pm & 0.44 & 33.01 & 75.36 & \pm & 4.27 & 960 & \pm & 0.38 \\
\hline DEC & 20.78 & 24.88 & \pm & 0.50 & 32.70 & 78.58 & \pm & 4.89 & 960 & \pm & 0.90 \\
\hline
\end{tabular}

In this way, it was decided to generate the bioclimatic charts for both climatic data to verify and compare the results suggested by the Analysis Bio software for both situations.

\section{RESULTS}

\subsection{BIOCLIMATIC CHART FOR TANGARÁ DA SERRA/MT, GENERATED FROM THE MONTHLY AVERAGE TEMPERATURE (PROVISIONAL WEATHER CONDITIONS)}

The Figure 6 presents the bioclimatic chart from Tangará da Serra/MT, generated from the provisional weather conditions, through the software Analysis Bio. In this image are arranged, in a psychrometric diagram, all the bioclimatic strategies, in addition to the months of the year resulting from the insertion of the values of the provisional weather conditions elaborated from the calculated averages. It is also noted that most of the periods are locate in the central quadrant, which corresponds to the condition of environmental comfort, pointing out that the local climate is pleasant for much of the year. 


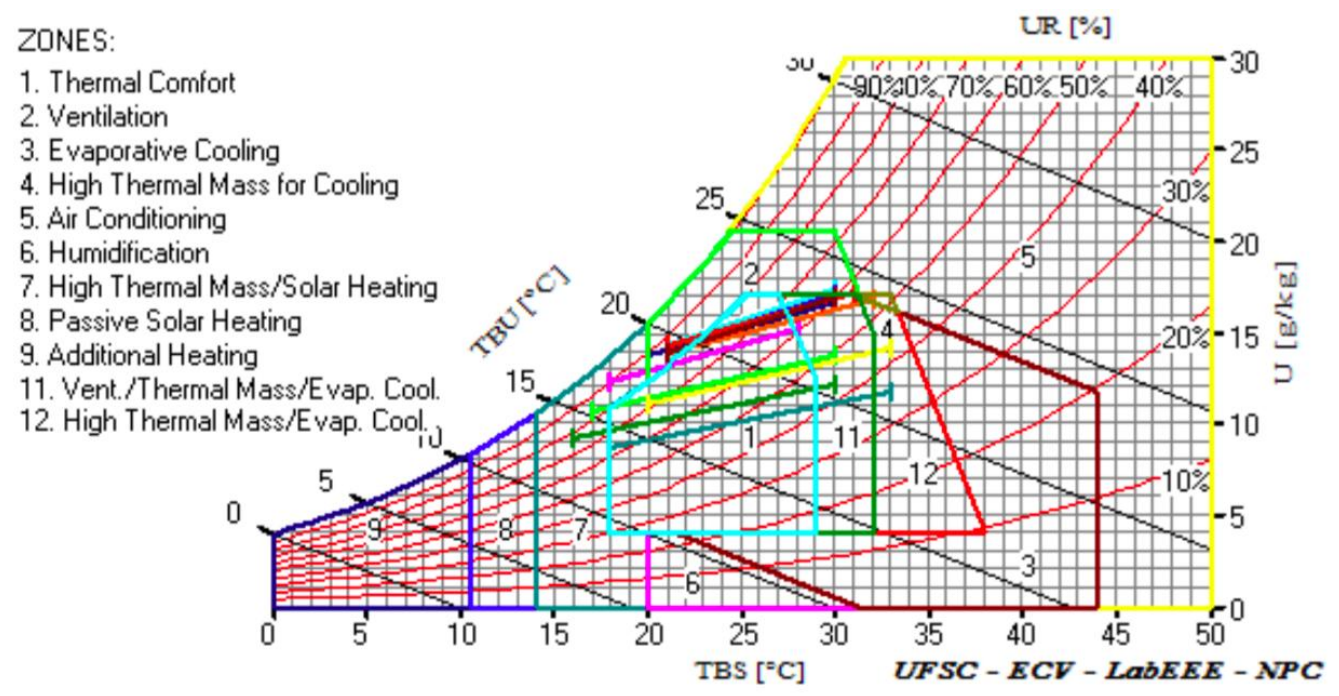

Figure 6 - Bioclimatic chart generated from the provisional weather conditions through Analysis Bio software for Tangará da Serra/MT. Source: Prepared by Analysis Bio software, adapted by the authors, 2019.

The software also allows visualizing this data through a report, which has been adapted and is exposed in Table 3. In this table, each month of the year presents a percentage that corresponds to the architectural strategies to provide building thermal comfort.

Table 3 - Monthly Bioclimatic Strategies for the city of Tangará da Serra/MT.

\begin{tabular}{|c|c|c|c|c|c|c|}
\hline & ZONE 01 & ZONE 02 & ZONE 04 & ZONE 07 & ZONE 11 & ZONE 12 \\
\hline JAN & $47.64 \%$ & $39.92 \%$ & & & $12.46 \%$ & \\
\hline FEB & $45.25 \%$ & $34.83 \%$ & & & $19.92 \%$ & \\
\hline MAR & $49.95 \%$ & $24.25 \%$ & & & $28.83 \%$ & \\
\hline APR & $48.94 \%$ & $25.75 \%$ & & & $25.80 \%$ & \\
\hline MAY & $98.06 \%$ & $10.06 \%$ & & $20.01 \%$ & $1.87 \%$ & \\
\hline JUN & $80.04 \%$ & & & $9.23 \%$ & $10.74 \%$ & \\
\hline JUL & $78.57 \%$ & & & $14.29 \%$ & $7.14 \%$ & \\
\hline AUG & $73.34 \%$ & & & & $20.00 \%$ & $6.67 \%$ \\
\hline SEP & $67.04 \%$ & & & & $25.27 \%$ & $7.70 \%$ \\
\hline OCT & $48.53 \%$ & $11.46 \%$ & $3.08 \%$ & & $34.44 \%$ & $2.51 \%$ \\
\hline NOV & $44.24 \%$ & $27.47 \%$ & & & $28.29 \%$ & \\
\hline DEC & $54.76 \%$ & $16.60 \%$ & & & $28.64 \%$ & \\
\hline
\end{tabular}

Obs.: Zone 01 - Thermal Comfort; Zone 02 - Natural Ventilation; Zone 04 High Inertia; Zone 07 - High Thermal Inertia/ Passive Solar Heating; Zone 11 Natural Ventilation / High Thermal Inertia / Evaporative Cooling; Zone 12 - High Thermal Inertia / Evaporative Cooling. 
The graph (Figure 7) synthesizes the bioclimatic strategies throughout the year, showing that the highest value refers to the comfort state $(61.36 \%$ days/year); followed by strategies (in descending order): Natural Ventilation (23,79\% days/year); Natural ventilation associated with high thermal inertia and evaporative cooling (20.28\% days/year); High thermal inertia and passive solar heating ( $14.51 \%$ days/year); high inertia and evaporative cooling $(5.63 \%$ days/year); and high thermal inertia for cooling (3.08\% days/year).

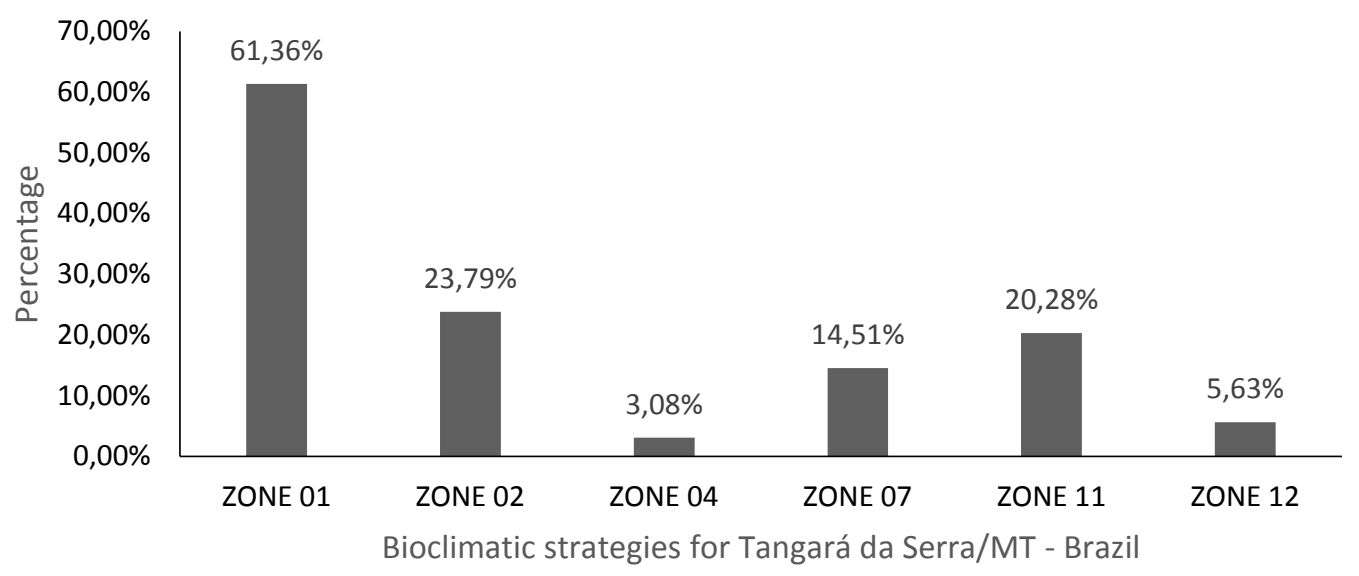

Figure 7 - Graph of percentages of bioclimatic strategies throughout the year: Zone 01 - Thermal comfort; Zone 02 - Natural ventilation; Zone 04 - High Inertia; Zone 07 High Thermal Inertia/ Passive Solar Heating; Zone 11 - Natural ventilation / High Thermal Inertia / Evaporative Cooling; Zone 12 - High Thermal Inertia / Evaporative Cooling.

\subsection{BIOCLIMATIC CHART FOR TANGARÁ DA SERRA/MT, FROM MEAN MAXIMUM AND MINIMUM ABSOLUTE TEMPERATURES}

The same procedure was performed using the minimum and maximum average absolute data, generating a second bioclimatic chart, shown in Figure 8. This one, compared to the previous, disregards Zone 4, which strategy corresponds to the high inertia for cooling. However, it includes two new strategies which are zones 3 and 5 that correspond, respectively, to evaporative cooling and air conditioning. 
ZONES:

1. Thermal Comfort

2. Ventilation

3. Evaporative Cooling

4. High Thermal Mass for Cooling

5. Air Conditioning

6. Humidification

7. High Thermal Mass/Solar Heating

8. Passive Solar Heating

9. Additional Heating

11. Vent./Thermal Mass/Evap. Cool

12. High Thermal Mass/Evap. Cool.j

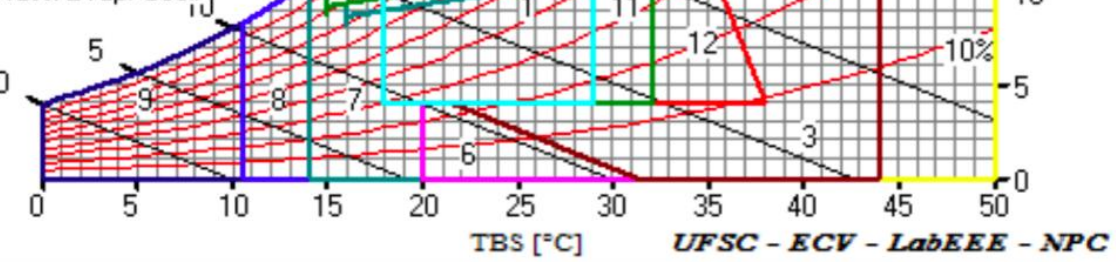

Figure 8 - Bioclimatic chart for Tangará da Serra/MT, from average maximum and absolute minimum temperatures. Source: Prepared by Analysis Bio software, adapted by the authors, 2019

The data generated in the software report are represented in Table 4.

Table 4 - Bioclimatic strategies generated from the minimum and maximum absolute temperatures for Tangará da Serra / MT per month.

\begin{tabular}{|c|c|c|c|c|c|c|c|}
\hline JAN & $42.71 \%$ & $31.24 \%$ & & & & $31.24 \%$ & \\
\hline FEB & $34.03 \%$ & $31.47 \%$ & & $6.43 \%$ & & $28.08 \%$ & \\
\hline MAR & $39.01 \%$ & $31.88 \%$ & & & & $29.11 \%$ & \\
\hline APR & $39.65 \%$ & $23.00 \%$ & & & $8.34 \%$ & $29.02 \%$ & \\
\hline MAU & $50.94 \%$ & $6.68 \%$ & & & $21.43 \%$ & $20.95 \%$ & \\
\hline JUN & $61.52 \%$ & & & & $23.83 \%$ & $14.65 \%$ & \\
\hline JUL & $64.71 \%$ & & & & $17.65 \%$ & $17.65 \%$ & \\
\hline AUG & $57.89 \%$ & & & & $10.53 \%$ & $15.79 \%$ & $15.79 \%$ \\
\hline SEP & $57.16 \%$ & & $9.90 \%$ & & $2.88 \%$ & $17.73 \%$ & $12.32 \%$ \\
\hline OCT & $37.13 \%$ & $17.64 \%$ & & $6.23 \%$ & $5.78 \%$ & $27.51 \%$ & $5.71 \%$ \\
\hline NOV & $33.62 \%$ & $23.79 \%$ & & $7.93 \%$ & $4.36 \%$ & $29.72 \%$ & $0.58 \%$ \\
\hline DEC & $62.50 \%$ & & & & & $37.50 \%$ & \\
\hline
\end{tabular}

Obs.: Zone 01 - Thermal comfort; Zone 02 - Natural ventilation; Zone 03 - Evaporative Cooling; Zone 05 - Air conditioning; Zone 07 - High Thermal Inertia/ Passive Solar Heating; Zone 11 - Natural ventilation / High Thermal Inertia / Evaporative Cooling; Zone 12 - High Thermal Inertia / Evaporative Cooling.

The graph (Figure 9) synthesizes the bioclimatic strategies throughout the year, showing the highest value refers to the comfort state $(48.41 \%$ 
days/year); followed by strategies (in descending order): natural ventilation, associated with high thermal inertia and evaporative cooling $(24.91 \%$ days/year); Natural ventilation (23.67\% days/year); High thermal inertia and passive solar heating $(11.85 \%$ days/year); evaporative cooling $(9.90 \%$ days/year); high thermal inertia and evaporative cooling (8.60\% days/year); and air conditioning ( $6.86 \%$ days/year).

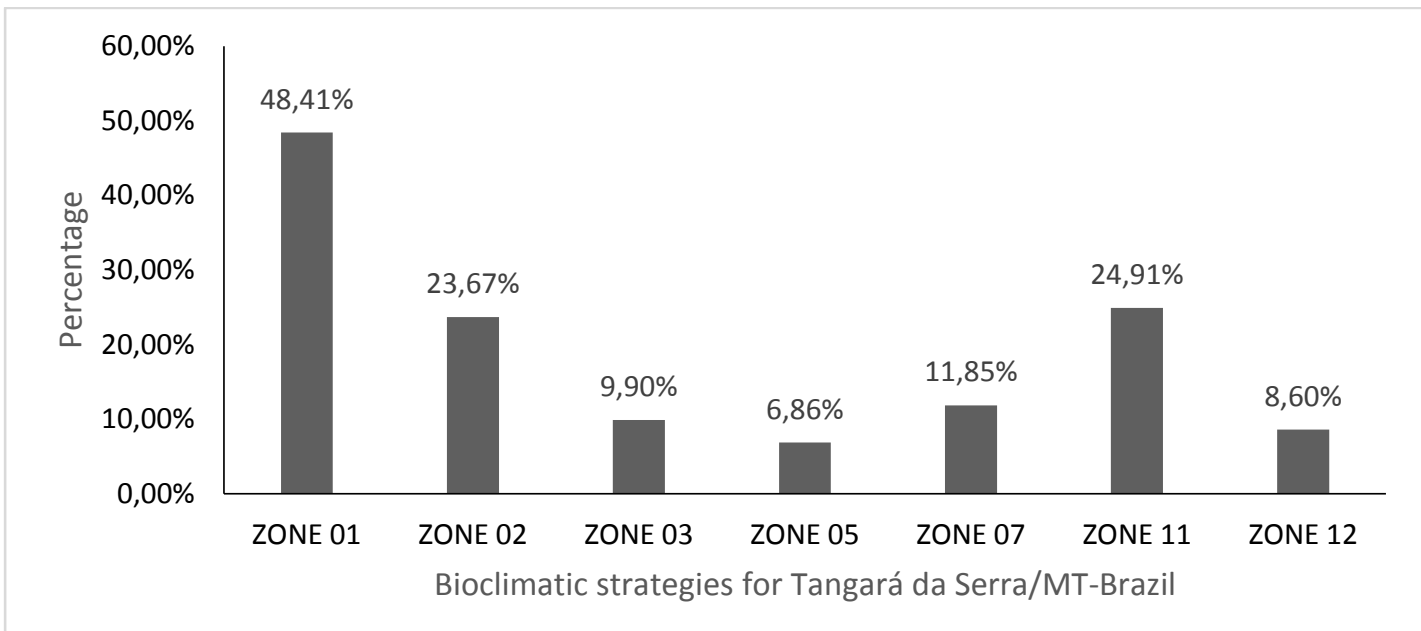

Figure 9 - Graph of percentages of bioclimatic strategies throughout the year: Zone 01 - Thermal comfort; Zone 02 - Natural ventilation; Zone 03 - Evaporative Cooling; Zone 05 - Air conditioning; Zone 07 - High Thermal Inertia/ Passive Solar Heating; Zone 11 Natural ventilation / High Thermal Inertia / Evaporative Cooling; Zone 12 - High Thermal Inertia / Evaporative Cooling.

Although the percentages presented by Analysis Bio are different for each generated chart, it is noticed that in both cases the results are proportional, thus validating the proposed bioclimatic strategies by means of the provisional weather conditions. Therefore, these will be considered since Analysis Bio requests, as input data, the average values obtained, thus providing the bioclimatic strategies appropriate to the local climate.

As shown previously, the environmental comfort presented in the results of the bioclimatic charts coincides with the periods of lower temperature (months of May to August). In this case, comfort in the built environment is guaranteed naturally, without the need to apply constructive strategies to achieve it.

Considering the normal provisional climatology, the results of this article show that Tangará da Serra - MT does not need artificial strategies to promote thermal comfort throughout the year. Even though it is characterized as a hot climate region, it is possible, through passive strategies, to promote thermal comfort, avoiding the need for refrigeration. energy conservation (KATAFYGIOTOU; SERGHIDES, 2015).

In periods of lower temperature the report presents, in values are not so expressive, the only strategy whose objective is to warm the environment: between May and July, passive solar heating associated with high thermal inertia of the building materials is suggested with $20.01 \%, 9.23 \%$ and $14.29 \%$ 
of the days of the month respectively. Therefore, it is proposed to use constructive techniques and materials for wrapping and covering that follow the specifications of NBR 15575 - Norma de Desempenho (ABNT, 2013). This strategy considers indirect passive solar heating, since it does not propose the use of openings or glazed surfaces which heat the environment due to the greenhouse effect (GIVONI, 1994).

However, during the other periods of the year (spring and summer), cooling strategies predominate, noting that natural ventilation is present in all months of the year in an isolated or combined way with other strategies. Sorgato, Melo and Lamberts (2016) point out that this strategy is the most important for Brazil and its use is recommended for places where the temperature varies between $20^{\circ} \mathrm{C}$ and $32^{\circ} \mathrm{C}$, and if the temperature is between $27^{\circ} \mathrm{C}$ and $32^{\circ} \mathrm{C}$, the ventilation is only efficient if the relative humidity is between $15 \%$ to $75 \%$. In Tangará da Serra, according to the averages calculated, the natural ventilation is efficient between December and April, that are the months in which the minimum and maximum temperatures presented lower thermal amplitude (below $10^{\circ} \mathrm{C}$ ).

The natural ventilation is fundamental for buildings because it exerts the function of renewing the air, besides promoting the psycho physiological and convective cooling. To exploit it, it is proposed the use of systems that allow: the chimney effect, whereby cold air, whose density is greater, exerts positive pressure, tending to descend, while hot air, whose density is smaller, exerts negative pressure, tending to rise, creating convection currents; cross ventilation, removing the heat by accelerating the exchanges by convection, in addition to raising the levels of evaporation, thus improving the thermal sensation in the internal environment (MANZANO-AGUGLIARO, et al., 2015; LABAKI; KOWALTOWSKI, 1993; LÔBO; BITTENCOURT, 2003).

Manzano-Agugliaro et al. (2015) also affirm that high thermal inertia is the characteristic that the materials possess of diminishing the internal thermal amplitudes, promoting a thermal delay in the heat flow, since these elements have the capacity to absorb and store heat. In cold periods, if properly oriented, the material stores heat during the day, releasing it at night, keeping the building warm, while in the summer it absorbs the heat in order to keep the building comfortable. This strategy is effective in warm climate regions, contributing to thermal comfort and reducing energy consumption in built environments (BUDAIWI; ABDOU; AL-HOMOUD, 2013; NOGUEIRA, et al., 2008).

In Tangará da Serra the high thermal inertia must be used along with other strategies: in winter it should be associated with passive solar heating; in the other months of the year, it should be associated with natural ventilation; and in August, September and October, which relative humidity has lower values, according to the calculated averages, should be associated with natural ventilation and evaporative cooling. This is based on evaporation of water, which removes heat from material on which the evaporation takes place or from the environment, being able to be of direct or indirect form. In Tangará da Serra natural ventilation is required, associated with high thermal inertia and evaporative cooling during $20.28 \%$ of the hours of the year. However, the strategy that considers only thermal inertia and evaporative cooling, disregarding natural ventilation, presents little expressive values $(5.63 \%$ 
days/year), according to the calculated averages and the report presented by Analysis Bio.

In this sense, it should be noted that, although there is a predominance of environmental comfort in the city of Tangará da Serra, the strategies are necessary to guarantee the maximum thermal comfort in buildings. The importance of natural ventilation strategies for cooling and also the thermal inertia is essential, since it favors both cooling (in the summer) and heating (in the winter).

Currently, there is a proposal to review the division of Brazilian bioclimatic zoning, which proposes to divide the country into 20 distinct zones, in addition to include other municipalities that until then were not listed. In this proposal, Tangará da Serra is classified as ZB 12, as shown in Figure 10 (RORIZ, 2012).

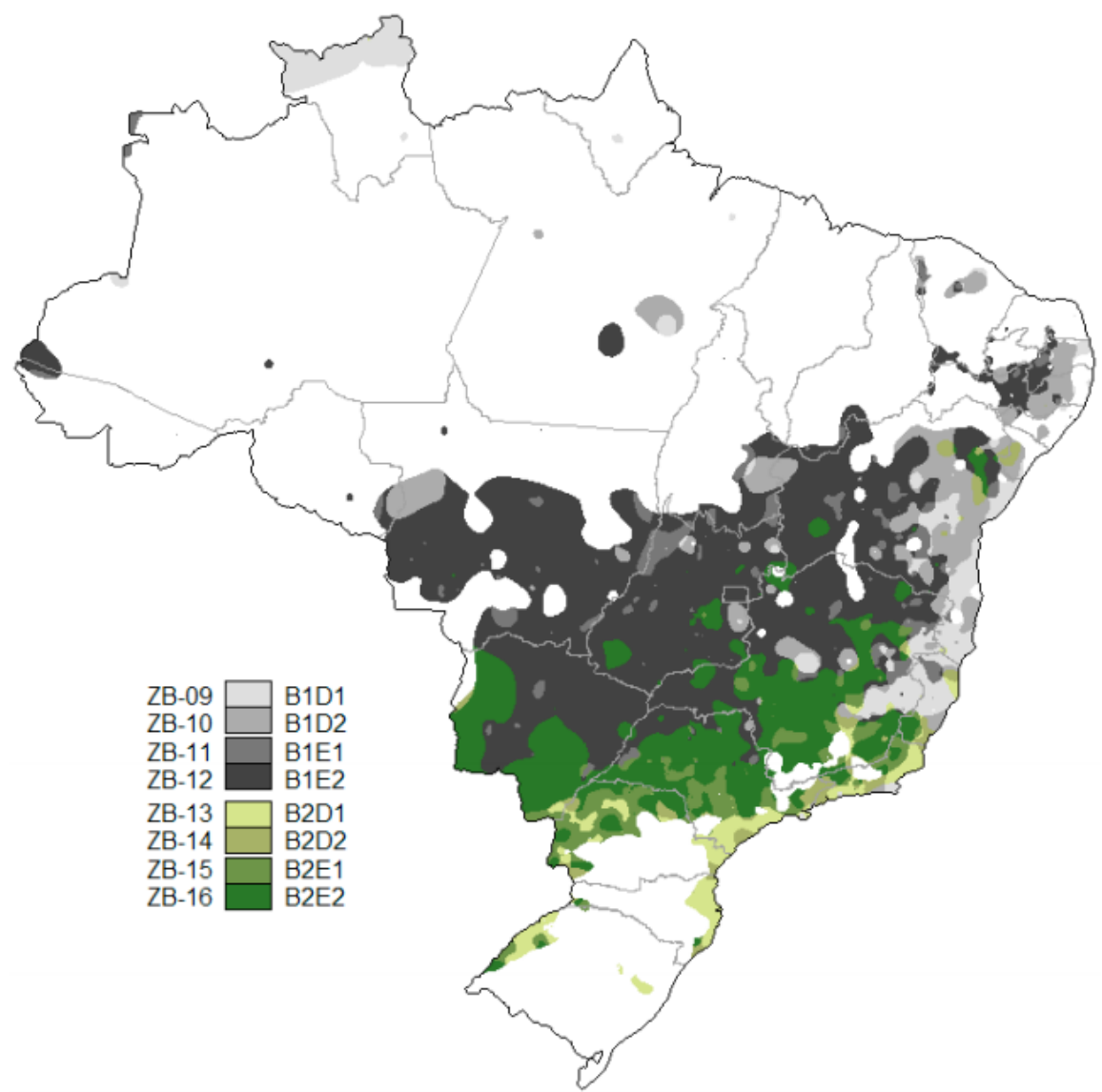

Figure 10 - Zones 9 to 16, average annual temperatures between 20 and $26{ }^{\circ} \mathrm{C}$ and approximate location of Tangará da Serra/MT. Source: RORIZ, 2012, adapted by the authors.

The values presented in the revision proposal are: Average annual air temperature equal to $25.33^{\circ} \mathrm{C}$; difference between the highest and the lowest monthly average temperature equal to $4.1^{\circ} \mathrm{C}$; annual average of the thermal amplitude equal to $10,09{ }^{\circ} \mathrm{C}$; and difference between the highest and lowest monthly thermal amplitude equal to $6.8^{\circ} \mathrm{C}$. However, these values differ from 
the data used for the accomplishment of this article, presenting approximate results only in annual average of the air temperature, which resulted in value of $24.75^{\circ} \mathrm{C}$, thus presenting a variation of $0.58{ }^{\circ} \mathrm{C}$. The difference between the values is due to the fact that the data used by Roriz (2012) were obtained by the Instituto Nacional de Meteorologia - INMET, which, although it has collected data from the municipality since 2002, does not have all data for all periods, in function of breaches and problems with automatic meteorological station used, possibly resulting in inconsistent values.

\section{CONCLUSION}

With this article was possible to contextualize issues related to thermal comfort and energy efficiency, emphasizing the importance of climate research for civil construction.

This work can contribute to elaboration of architectural projects that are coherent to climatic reality of Tangará da Serra - MT, guaranteeing that buildings have comfortable and energy efficient environments, so the use of artificial instruments for environmental conditioning can be mitigated.

As a result of this study, the local bioclimatic chart was obtained, elaborated with the intention of presenting bioclimatic strategies appropriate to Tangará da Serra - MT climate. Through this, it was concluded that municipality is, predominantly, in thermal comfort, proving to be a city of pleasant climate. However, it is necessary to adopt strategies that allow cooling the built environments during the summer and winter periods besides suggesting passive solar heating during winter.

For cooling, the results of this research propose natural ventilation as main bioclimatic strategy to be adopted, being essential throughout all months of the year. In addition, in some periods, the evaporative cooling and the high inertia of envelope materials must be associated in order to guarantee comfort conditions in the building. For this, it is important to emphasize the cross ventilation and the chimney effect, which allow the exchange of air between external and internal environments, becoming an effective tool for a better thermal performance of the building. The envelope choice materials also influence the heat of environments; therefore, it is suggested the adoption of materials of high thermal inertia, capable of delaying the entrance of heat in environments, making them more comfortable. The same strategy is applied to the cold period, although this situation is less frequent throughout the year. It is proposed to adopt materials of high inertia in order to reduce the thermal exchange between internal and external environment, keeping the environments warmer for longer.

Finally, this article proposes new research in the city, both in what concerns the issues of climate in urban and rural microclimate, as well as researches that can measure the incidence, speed and direction of local winds, and experiments that prove effectiveness of the strategies presented here in an applied scale. 


\section{REFERENCES}

ALMEIDA, Hermes Alves de. Climatologia aplicada à geografia (Livro eletrônico). Hermes Alves de Almeida. Campina Grande: EDUEPB, 2016.

ASSOCIAÇÃO BRASILEIRA DE NORMAS TÉCNICAS - ABNT. NBR 15220 Desempenho Térmico de Edificações. Rio de Janeiro: ABNT, 2005a.

. NBR 15220-3 - Desempenho térmico de edificações - Zoneamento bioclimático brasileiro e diretrizes construtivas para habitaç̃oses unifamiliares de interesse social. Rio de Janeiro, 2005b.

- NBR 15575 - Edifícios habitacionais de até cinco pavimentos -

Desempenho. Rio de Janeiro, 2013.

BRAGA, B.; HESPANHOL, I.; CONEJO, J. G. L. Introdução a engenharia ambiental. São Paulo: Prentice Hall, 2003.

BROWN, G. Z.; DEKAY, M. Sol, vento e luz: estratégia para projeto de arquitetura. Trad. Alexandre Ferreira da Silva Salvaterra. Brookman, 2 ed. Porto Alegre, 2004.

BUDAIWI, Ismail M.; ABDOU, Adel A.; AL-HOMOUD, Mohammad S. Envelope retrofit and air-conditioning operational strategies for reduced energy consumption in mosques in hot climates. Building Simulation, v. 6, n. 1, p. 3350, 2013.

CARLOS, Claudio Antonio Santos Lima. Arquitetura do Ferro do Rio de Janeiro. Mobilidade posta à prova. ARQUISUR Revista. Santa Fe, Argentina, v. 3, n. 3, p. 96-109, 2013. Available at: < https://doaj.org/article/b2a1b9a222ac4f8a9a9d67d60cf82085 >, access in March 2019.

COLIN, Silvio. Uma introdução à arquitetura. Rio de Janeiro: Uapê, 2000.

COSTA, Maria Lívia; FREIRE, Marcia Rebouças; KIPERSTOK, Asher. Strategies for thermal comfort in university buildings - The case of the faculty of architecture at the Federal University of Bahia, Brazil. Journal of Environmental Management, v. 239, n. February, p. 114-123, 2019. Available at: <https://doi.org/10.1016/j.jenvman.2019.03.004>, access in April 2019.

DALLACORT, $R$, et al. Distribuição das chuvas no município de Tangará da Serra, médio norte do Estado de Mato Grosso, Brasil. Acta Scientiarum. Agronomy. Maringá, v. 33, n2, p. 193-200, 2011. Available at: < http://www.scielo.br/pdf/asagr/v33n2/01.pdf >, access in January 2019.

DE DEAR, Richard J.; BRAGER, Gail S. Thermal comfort in naturally ventilated buildings: Revisions to ASHRAE Standard 55. Energy and Buildings, v. 34, n. 6, p. 549-561, 2002.

ELETROBRAS. Pesquisa de posse de equipamentos e hábitos de uso, ano base 2005: classe Residencial Relatório Brasil - Sumário Executivo. Avaliação do Mercado de Eficiência Energética no Brasil. Rio de Janeiro: ELETROBRAS; PROCEL, 2007.

ESPÍ, Mariano Vásquez. Uma brevísima história de la arquitectura solar. Edita: Instituto Juan de Herrera, 1999. 
FROTA, A. B.; SCHIFFER, S. R. Manual de conforto térmico: arquitetura, urbanismo. 5. Ed. - São Paulo: Studio Nobel, 2001.

GABRIEL, Luana F. et al. Variabilidade Interanual da Pressão Atmosférica Associada ao Fenômeno El Niño Oscilação Sul em Santa Maria, RS. Ciência e Natura, [S.I.], p. 367-370, nov. 2011. ISSN 2179-460X. Available at: <https://periodicos.ufsm.br/cienciaenatura/article/view/9461/5612 > .Access date: 14 july 2019. doi:http://dx.doi.org/10.5902/2179460X9461.

GIVONI, Baruch. Comfort Climate Analysis and Building Design Guidelines. Energy and Buildings, 1992.

GIVONI, B. Passive and low energy cooling of buildings. Van Nostrand Reinhold publishing company, 1994.

GUAN, Lisa. Energy use, indoor temperature and possible adaptation strategies for air-conditioned office buildings in face of global warming. Building and Environment, v. 55, p. 8-19, 2012. Available at: <http://dx.doi.org/10.1016/j.buildenv.2011.11.013>, access in April 2019.

INSTITUTO BRASILEIRO DE GEOGRAFIA E ESTATÍSTICA - IBGE. Cidades. Tangará da Serra - MT. Available at: < https://cidades.ibge.gov.br/brasil/mt/tangara-da-serra/panorama >, access in February 2019.

INSTITUTO NACIONAL DE METEOROLOGIA - INMET. Ministério da Agricultura, pecuária e Abastecimento. Normais Climatológicas do Brasil. Available at: < http://www.inmet.gov.br/portal/index.php?r=clima/normaisclimatologicas >, access in February 2019.

KATAFYGIOTOU, M. C.; SERGHIDES, D. K. Bioclimatic chart analysis in three climate zones in Cyprus. Indoor and Built Environment, v. 24, n. 6, p. 746-760, 2015.

KOWALTOWSKI, Doris C.C.K.; LABAKI, Lucila C. O Projeto Arquitetônico e o Conforto Ambiental: Necessidade de uma Metodologia. Anais do ENTAC 1993 V Encontro Nacional de Tecnologia do Ambiente Construído, Avanços em Tecnologia e Gestão da Produção de Edificações, São Paulo, SP. 1993. p. 785794.

LAMBERTS, R.; DUTRA, L.; PEREIRA, F. Eficiência Energética na Arquitetura. São Paulo: PW, 1997.

LAMBERTS, R; NARANJO, A. Desempenho Térmico de Edificações. Florianópolis: Apostila - Universidade Federal de Santa Catarina, 2016.

LAMOTTA, M. G.; LABAKI, L. C. Dez Anos Depois: Estudo do Clima de Campinas. Caracterização e Proposição de Recomendações de Projeto para Climas Compostos em 1998 e em 2008 - O Que Mudou. In: X Encontro Nacional e VI Encontro Latino-americano de Conforto no Ambiente Construído, Natal, 2009, p. 432. Available

at: <http://www.infohab.org.br/encac/files/2009/ENCAC09_0431_440.pdf>, access in November 2018.

LI, Ke; LIN, Boqiang. Impacts of urbanization and industrialization on energy consumption/CO2 emissions: Does the level of development matter?. Renewable and Sustainable Energy Reviews. Elsevier v. 52, p. 1107-1122. 2015. Available 
at:

https://www.sciencedirect.ez316.periodicos.capes.gov.br/science/article/pii/S13 64032115008321 >, access in April 2019.

LÔBO, Denise Gonçalves Ferreira; BITTENCOURT, Leonardo Salazar. A influência dos captadores de vento na ventilação natural de habitações populares localizadas em climas quentes e úmidos. Ambiente Construído, v. 3, n. 2, p. 5767 , 2003. Available at: <http://www.seer.ufrgs.br/ambienteconstruido/article/viewArticle/3451\%5Cnhtt p://www.seer.ufrgs.br/ambienteconstruido/article/download/3451/1870>, access in April 2019.

MANZANO-AGUGLIARO, F.; MONTOYA, F. G.; SABIO-ORTEGA, A.; GARCÍACRUZ, A. Review of bioclimatic architecture strategies for achieving termal comfort. Renewable and Sustainable Energy Reviews. Elsevier, v. 49, p. 736755. 2015. Available at: < https://www.sciencedirect.com/science/article/pii/S1364032115003652?via\%3D ihub >, access in April 2019.

MARCUZZO, Francisco Fernando Noronha; ROCHA, Hudson Moraes; MELO, Denise Christina de Rezende Melo. Mapeamento da precipitação pluviométrica no bioma cerrado do estado de Mato Grosso. Boletim Goiano De Geografia, 31(2), 83-97, 2012. Available at: < https://doi.org/10.5216/bgg.v31i2.16847 $>$, access in July 2019.

MATEUS, Ricardo. Avaliação da Sustentabilidade da Construção - Propostas para o Desenvolvimento de Edifícios mais sustentáveis. Doctoral Thesis in Civil Engineering. University of Minho, 2009.

MATO GROSSO. Geografia. 2018. Available in: <http://www.mt.gov.br/geografia>, access in November 2018.

MORENO, Ana Cecília Rodrigues; MORAIS, Ingrid Stephanie De; SOUZA, Robertavieira Gonçalves De. Thermal Performance of Social Housing-A Study Based on Brazilian Regulations. Energy Procedia, v. 111, n. September 2016, p. 111-120, 2017. Available at: <http://dx.doi.org/10.1016/j.egypro.2017.03.013>, access in April 2019.

NEPEC. Núcleo de extensão e pesquisas econômicas e contábeis. Perfil socioeconômico de Tangará da Serra. 2011. Available at: <http://www2.unemat.br/nepec/perfil_tangara>. Access in December 2018.

LEÃO, Marlon et al. Thermal performance in three different low-cost dwellings for the tropical climate of Brazil. Bauphysik, v. 30, n. 1, p. 33-37, 2008.

OLGYAY, V. Design with Climate. Bioclimatic Approach to Architectural Regionalism. 1963. 4th ed. Princeton, New Jersey. USA: Princeton University Press. 1963.

OUAHRANI, Djamel; AL TOUMA, Albert. Selection of slat separation-to-width ratio of brise-soleil shading considering energy savings, $\mathrm{CO} 2$ emissions and visual comfort - a case study in Qatar. Energy and Buildings, v. 165, p. 440450, 2018. Available at: <https://doi.org/10.1016/j.enbuild.2017.12.053>, access in April 2019.

POLIÃO, Marco Vitruvio. Da arquitetura. 2. ed. São Paulo: Hucitec, 2002, p.143. 
PALHANA MOREIRA, Patricia Simone et al. Ciclo diário de variáveis meteorológicas nos biomas do estado de Mato Grosso (Meteorological variables daily cycle in Mato Grosso State biomes. Revista Brasileira de Climatologia, [S.I.], v. 17, dez. 2015. ISSN 2237-8642. Available at: <https://revistas.ufpr.br/revistaabclima/article/view/41159/27316>. Access in January 2019.

ROMERO, Marcelo de Andrade; REIS, Lineu Belico dos. Eficiência energética em edifícios. Manole Ltda., Barueri - SP, 2012.

RORIZ, Maurício. Uma proposta de revisão do Zoneamento Bioclimático Brasileiro. 2012. Available at: < http://www.labeee.ufsc.br/projetos/propostade-revisao-do-zoneamento-bioclimatico-brasileiro > , access in March 2019.

RUPP, Ricardo Forgiarini; GHISI, Enedir. What is the most adequate method to assess thermal comfort in hybrid commercial buildings located in hot-humid summer climate? Renewable and Sustainable Energy Reviews, v. 29, p. 449462, 2014. Available at: <http://dx.doi.org/10.1016/j.rser.2013.08.102>.

RUPP, Ricardo Forgiarini; VÁSQUEZ, Natalia Giraldo; LAMBERTS, Roberto. A review of human thermal comfort in the built environment. Energy and Buildings, v. 105, p. 178-205, 2015. Available at: <http://dx.doi.org/10.1016/j.enbuild.2015.07.047>, access in April 2019.

SORGATO, M. J.; MELO, A. P.; LAMBERTS, R. The effect of window opening ventilation control on residential building energy consumption. Energy and Buildings, v. 133, p. 1-13, 2016. Available at: <http://dx.doi.org/10.1016/j.enbuild.2016.09.059>, access in April 2019.

SPINELLI, Rodrigo; KONRAD, Odorico; CAMBEIRO, F.Patiño; AHLERT, Edson; SPINELLI, Fabiana; QUADROS, Eric Augusto. Bioclimatic strategies for the city of Lajeado/RS-Brazil, using data analysis of regional climate. Revista Brasileira de Climatologia. Curitiba, ano 13, v. 21, p. 153-171, jul/dez. 2017, ISSN 22378642. Available at < http://revistas.ufpr.br/revistaabclima/article/view/50554 $>$, access in November 2018.

SOUTULLO, S. et al. Comparative thermal study between conventional and bioclimatic office buildings. Building and Environment, v. 105, p. 95-103, 2016. Available at: https://www.sciencedirect.com/science/article/pii/S036013231630169X access in April 2019.

STERLING, Theodor D.; COLLET, Chris; RUMEL, Davi. A epidemiologia dos "edifícios doentes". Rev. Saúde Públ. São Paulo, vol. 25, pag. 56-63. 1991. Available at: < http://www.scielo.br/pdf/rsp/v25n1/12.pdf >, access in February 2019.

THOENES, Christof. Teoria da arquitetura do renascimento aos nossos dias. Köln: Benedikt Taschen, 2003.

TIKOPOULOS, Argiris F.; KARATZA, Marianthi C.; PARAVANTIS, John. Modeling energy efficiency of bioclimatic buildings. Energy and Buildings. Elsevier, v. 37, n. 5, pg. 529-544, 2004. Available at:< https://doi.org.ez316.periodicos.capes.gov.br/10.1016/j.enbuild.2004.09.002 $>$, access in April 2019. 
TRIANA, Maria Andrea; LAMBERTS, Roberto; SASSI, Paola. Should we consider climate change for Brazilian social housing? Assessment of energy efficiency adaptation measures. Energy and Buildings, v. 158, p. 1379-1392, 2018. Available at: <http://dx.doi.org/10.1016/j.enbuild.2017.11.003>, access in March 2019.

VERBEKE, Stijn; AUDENAERT, Amaryllis. Thermal inertia in buildings: A review of impacts across climate and building use. Renewable and Sustainable Energy Reviews, v. 82, n. May 2017, p. 2300-2318, 2018. Available at: <https://doi.org/10.1016/j.rser.2017.08.083>, access in May 2019. 